\title{
Learners' Learning Readiness as a Foundation for Achieving Learning Success
}

Pairin

Fakultas Tarbiyah dan Ilmu Keguruan IAIN Kendari email: pairin@iainkendari.ac.id

\begin{abstract}
This article aims to provide an overview of learners 'learning readiness, which includes the relationship of motivation to learning readiness, as well as the relationship of parents' attention to learning readiness. The method used in this study is the study of library materials, which are related to learning readiness. Reading material is limited only in the last ten years. The results of the study indicate that learning success is largely determined by physical, psychological, and initial knowledge about the subject to be faced. Therefore, students must ensure their readiness comprehensively. This responsibility must start from the family environment, then by the school through the conditioning of a conducive learning environment. Psychologically, learning readiness can be influenced by motivation, both internally and externally. Students should not be left trapped in external impulses that are temporary in following learning. Instead, students are directed to the deepest awareness of their main mission in participating in learning. Sociologically, the role of the family through high attention can also be an important factor in achieving learning success.
\end{abstract}

Keywords: Learning Readiness, Motivation, Attention 
Kesiapan Belajar Peserta Didik sebagai Fondasi Mencapai Kesuksesan Belajar

Pairin

Fakultas Tarbiyah dan Ilmu Keguruan IAIN Kendari email: pairin@iainkendari.ac.id

\begin{abstract}
Abstrak
Artikel ini bertujuan memberikan ulasan mengenai kesiapan belajar peserta didik, yang mencakup relasi motivasi dengan kesiapan belajar, serta relasi perhatian orang tua dengan kesiapan belajar. Metode yang digunakan dalam kajian ini adalah pengkajian bahanbahan pustaka, yang terkait dengan kesiapan belajar. Bahan bacaan dibatasi hanya dalam kurun waktu sepuluh tahun terakhir. Hasil kajian menunjukkan bahwa kesuksesan belajar sangat ditentukan oleh kondisi fisik, psikis, dan pengetahuan awal tentang pelajaran yang akan dihadapi. Karenanya, peserta didik harus memastikan kesiapan dirinya secara komprehensif. Tanggung jawab ini harus dimulai dari lingkungan keluarga, selanjutnya oleh sekolah melalui pengkondisian lingkungan belajar yang kondusif. Secara psikologis, kesiapan belajar dapat dipengaruhi oleh motivasi, baik secara internal maupun eksternal. Peserta didik tidak boleh dibiarkan terjebak pada dorongandorongan eksternal yang bersifat sementara dalam mengikuti pembelajaran. Sebaliknya, peserta didik diarahkan pada kesadaran terdalam tentang misi utamanya dalam mengikuti pembelajaran. Secara sosiologis, peran keluarga melalui perhatian yang tinggi dapat menjadi faktor penting pula dalam meraih kesuksesan belajar.
\end{abstract}

Kata Kunci: Kesiapan Belajar, Motivasi, Perhatian 


\section{Introduction}

Education is the main capital in facing challenges in this globalization era ${ }^{1}$. Education is a process of maturity consciously and planned to optimize the potential of students, so that the character, character, and personality are formed as a whole person. Good education is expected to improve and develop the full potential of students so that they become better human beings ${ }^{2}$. Hopes for the presence of quality human resources through schooling are hung as much as possible on the teacher.

Teachers are not only required to be able to teach science but rather prioritize educating and guiding children to become qualified human beings ${ }^{3}$. So that educators have a great responsibility for success in the teaching and learning process. The whole learning process at school is the most basic and main activity. In this case means the success or failure of learning depends on the learning process experienced by children.

The success of educational programs through the teaching and learning process, one of which is influenced by students ${ }^{4}$. Because students are the basis and purpose of organizing education. The task of the teacher and the school (in a broader context) provides certainty related to learning readiness, which will determine learning success ${ }^{5}$. Learning readiness must also be supported by conducive family conditions for students, through high attention to children's education.

This paper tries to provide an overview of the variables related to students 'learning readiness, which in this study are limited to variables of learning motivation and parents' attention.

1 Dacholfany, M. I. (2015). Reformasi Pendidikan Islam Dalam Menghadapi Era Globalisasi. AKADEMIKA: Jurnal Pemikiran Islam, 20(1), 173194.

${ }^{2}$ Amaliah, D. (2016). Pengaruh Partisipasi Pendidikan Terhadap Persentase Penduduk Miskin. Faktor Jurnal Ilmiah Kependidikan, 2(3).

3 Aslamiyah, S. S., Ag, S., \& Lamongan, F. A. I. U. I. (2016). Profesionalisme Guru Dalam Perspektif Islam. Jurnal Akademika, 10(2), 180.

4 Rahman, A. R. (2011). Pengaruh motivasi, lingkungan dan disiplin terhadap prestasi belajar siswa pada jurusan teknik audio video SMK Negeri 3 Yogyakarta. Jurnal. Program Studi Pendidikan Teknik Elektronika. Universitas Negeri Yogyakarta.(eprints. uny. ac. id/9495/1/Jurnal. pd. di akses September 2014).

5 Mulyani, D. (2013). Hubungan kesiapan belajar siswa dengan prestasi belajar. Konselor, 2(1). 


\section{Method}

This study is a literature review in which the material used is literature that is relevant to the topic of students' readiness of learning. The literature used as study material is prioritized from primary sources, namely scientific journal articles and proceeding articles, as well as research results. The literature is limited only in the last 10 years (longest published 2009). Presentation techniques through the discussion of each variable, then the discussion about the relations between variables is carried out. Then drawing conclusions.

\section{Conceptual Review}

\section{A. Learning Readiness}

Learning readiness is very important as a foundation in the learning process. Without the readiness of the learning process will not be maximized. If students are ready to do the learning process, good learning outcomes will be obtained. Conversely, if students are not ready to learn, good results will not be obtained. Therefore, learning should be done if individuals have readiness to learn ${ }^{6}$.

Learning readiness are conditions that precede learning activities $^{7}$. Learning readiness is a person's ability to benefit from the learning experience he finds ${ }^{8}$. So that learning readiness is a person's ability both physically and mentally to conduct learning activities.

\section{B. Parents Attention}

Attention is more or less awareness that accompanies something done activities ${ }^{9}$. Mindfulness as one of the psychic activities, can be understood as the activity of the soul which is heightened. The soul is solely focused on an object (objects or things)

6 Jumasrin, J. (2019). Variabel-Variabel Relasional Kesiapan Belajar Peserta Didik di Tingkat Sekolah Dasar. Shautut Tarbiyah, 25(1), 84-107.

${ }^{7}$ Harmini, T. (2017). Pengaruh Kesiapan Belajar Terhadap Prestasi Belajar Mahasiswa Pada Pembelajaran Kalkulus. Mathline: Jurnal Matematika dan Pendidikan Matematika, 2(2), 145-158.

8 Jumasrin, J. (2019). Variabel-Variabel Relasional Kesiapan Belajar Peserta Didik di Tingkat Sekolah Dasar. Shautut Tarbiyah, 25(1), 84-107.

${ }^{9}$ Wasti, S. (2013). Hubungan Minat Belajar Dengan Hasil Belajar Mata Pelajaran Tata Busana Di Madrasah Aliyah Negeri 2 Padang. E-Journal Home Economic and Tourism, 2(1). 
or a collection of objects ${ }^{10}$. Attention is the concentration of energy/soul force focused on an object ${ }^{11}$.

Attention can be obtained from anyone, can be from teachers or parents. The parents referred to in this study are the father and mother who gave birth to children and are obliged to care for, care for, and educate the child so that they become qualified human beings. The first knowledge received by children is from their parents. So parents have an important role in the education of their children. Parents are men and women who are bound in marriage and are ready to assume the responsibilities of being the father and mother of the children they are born with.

It can be concluded that parental attention is the process of providing parental assistance to their children, providing tutoring at home, encouraging learning, giving direction to the importance of learning, paying attention to the needs of tools that support learning for optimal learning achievement.

The forms of parental attention, are as follows:

1. Give a warning.

2. Give warning.

3. Paying attention to the provision of study facilities.

4. Provision and arrangement of children's learning time.

5. Help solve the problem.

6. Supervision of children's learning.

7. Provision of Learning Facilities ${ }^{12}$.

Thus, the forms of parental attention in children's education can be interpreted as managing the educational needs of children. Therefore, parents will think about the various educational needs of children, provide appropriate facilities, control children's learning activities and children's daily behavior, and it is very important to assess the child's learning progress.

${ }^{10}$ Chandra, A. (2018). Hubungan Perhatian Orang Tua dan Iklim Sekolah dengan Disiplin pada Siswa SMP N 2 Padang Tualang Kabupaten Langkat. Jurnal Psychomutiara, 1(1), 1-14.

11 Angraini, S. (2018). Pengaruh Penggunaan Media Pembelajaran Lcd Projector Terhadap Perhatian Siswa Dalam Pembelajaran Ekonomi Di Sekolah Menengah Atas Negeri 1 Kampar (Doctoral dissertation, Universitas Islam Negeri Sultan Syarif Kasim Riau).

12 Jumasrin, J. (2019). Variabel-Variabel Relasional Kesiapan Belajar Peserta Didik di Tingkat Sekolah Dasar. Shautut Tarbiyah, 25(1), 84-107. 
Attention is influenced by objective factors, namely strong stimuli get attention, the quality of stimuli affects attention, large objects attract attention, so also stimuli can attract attention. In addition, there are also subjective factors, namely things related to the subject person, for example: some stimuli that are in accordance with their talents are more interesting than others ${ }^{13}$.

Objective factors that can attract a person's attention are strong stimuli, quality of stimuli, large / broad objects, and new stimuli. While the subjective factors that can attract attention are interesting stimuli, meaning or intent on an object or subject, uncertainty gives rise to attractiveness, and motions that can still determine attractiveness ${ }^{14}$.

Parents have a very sensitive feeling towards their children. If the child is seen as being seen as different from the usual situation, then parents with a very strong stimulus to immediately give attention to the child in order to provide something that is needed. For example, children look glum, then parents immediately pay attention so that the child can free from the moodiness.

Parents in giving attention to children are not continuous, but can choose if the child is in dire need of attention. This can occur when the child is facing tests for example. So parents consider that the situation at that time really needs attention so that children can learn seriously. The situation facing tests is one example of the quality of stimuli that makes parents pay attention.

Everyone has emotions or impulses stored in the heart, this can arise if there are objects that can attract attention suddenly unexpectedly, so that attention arises with a very strong or extraordinary impulse. For example, parents have a desire in their hearts so that their children can achieve high achievements, if really the child can realize the wishes of these parents, then the child will get greater attention.

Children are expected to develop according to their potential. If in its development has creativity towards positive things, then parents will also pay attention to support these activities. Children will

13 Jumasrin, J. (2019). Variabel-Variabel Relasional Kesiapan Belajar Peserta Didik di Tingkat Sekolah Dasar. Shautut Tarbiyah, 25(1), 84-107.

14 Jumasrin, J. (2019). Variabel-Variabel Relasional Kesiapan Belajar Peserta Didik di Tingkat Sekolah Dasar. Shautut Tarbiyah, 25(1), 84-107. 
easily remember if there is something that catches their attention. Parents can use this to help the child's learning process at home. Parents can give picture books, interactive CDs or learning games that attract children's attention and are fun.

Raising the attraction of children can be done by the use of interesting words. Parents in providing tutoring and advice to their children can be done using stories or fairy tales, so that children feel happy and easy to receive information conveyed by parents. Attracting a child's attention can also be done by making the child feel curious. Sometimes parents don't have to always answer what the child asks, and fulfill everything the child wants. Make the child wait in uncertainty and eventually the child will find their own answers. This will make the child independent, arising curiosity and challenge.

The situation of parents' feelings is very influential on children's interest in learning. This can happen if parents who work happy feelings will create a pleasant home atmosphere. Conversely, parents who work with feelings of anger make the home atmosphere less pleasant so that the interest in learning for children is reduced / decreasing. Parents should always maintain their emotions, especially in front of children.

Based on an explanation of the factors that influence parental attention, it can be concluded that parental attention can be influenced by two factors namely objective and subjective factors. Objective factors tend to arise due to encouragement from within the individual, while subjective factors tend to arise from outside the individual self. Both of these factors for parents can appear alone or together depending on the object being faced. The attention of parents given to their children is very influential on children's development, especially in learning interests and other activities that can make a positive contribution to children.

\section{Learning Motivation}

Motivation can be said as a mental impulse that moves to do certain activities to achieve a goal ${ }^{15}$. Motivation is an impulse that converts energy in a person into tangible activities to achieve certain

15 Idzhar, A. (2016). Peranan Guru dalam Meningkatkan Motivasi Belajar Siswa. Jurnal office, 2(2), 221-228. 
goals ${ }^{16}$. Motivation is a condition found in a person that drives him to do certain activities in order to achieve a goal. Motivation can also be in the form of efforts that can cause someone to be moved to do something because they want to achieve the goals they want or get satisfaction with their actions ${ }^{17}$. While learning motivation is the tendency of students to carry out learning activities that are driven by a desire to achieve the best possible learning achievements or results ${ }^{18}$. Learning motivation is a psychological factor that is nonintellectual. His role is in terms of growing passion, feeling happy and eager to learn. Students who have a passion for learning will more easily understand the learning material, so that learning objectives will be achieved ${ }^{19}$. Learning motivation is an impetus/activator and selectors for learning ${ }^{20}$.

Based on some of the opinions above, it can be concluded that learning motivation is an encouragement that arises from within a person to carry out learning activities in order to achieve optimal learning achievement.

At least there are several motivational principles in learning, namely: 1) Motivation as a driving force that encourages learning activities; 2) Intrinsic motivation is more important than extrinsic motivation in learning; 3) Motivation in the form of praise is better than punishment; 4) Motivation is closely related to learning needs; 5) Motivation can foster optimism in learning; 6) Motivation breeds achievement in learning $^{21}$.

Motivation starts an energy change in every individual. Because motivation involves changes in human energy, the appearance will involve human physical activity. Motivation is

16 Manizar, E. (2015). Peran Guru Sebagai Motivator dalam Belajar. Tadrib: Jurnal Pendidikan Agama Islam, 1(2), 204-222.

${ }^{17}$ Prihartanta, W. (2015). Teori-teori motivasi. Jurnal Adabiya, 1(83), 1-14.

18 Hamdu, G., \& Agustina, L. (2011). Pengaruh motivasi belajar siswa terhadap prestasi belajar IPA di sekolah dasar. Jurnal penelitian pendidikan, 12(1), 90-96.

${ }^{19}$ Thaib, E. N. (2013). Hubungan Antara prestasi belajar dengan kecerdasan emosional. JURNAL ILMIAH DIDAKTIKA: Media Ilmiah Pendidikan dan Pengajaran, 13(2).

${ }^{20}$ Jumasrin, J. (2019). Variabel-Variabel Relasional Kesiapan Belajar Peserta Didik di Tingkat Sekolah Dasar. Shautut Tarbiyah, 25(1), 84-107.

21 Jumasrin, J. (2019). Variabel-Variabel Relasional Kesiapan Belajar Peserta Didik di Tingkat Sekolah Dasar. Shautut Tarbiyah, 25(1), 84-107. 
marked by the emergence of a person's sense of affection. Motivation is relevant to psychiatric problems, affections and emotions that can determine human behavior. Motivation will be stimulated because of goals. Motivation arises from within a person, but its emergence because it is stimulated by the presence of other elements, in this case is the goal $^{22}$.

Some ways that can be done to grow students' motivation in learning activities, i.e.:

1. Give numbers, in this case numbers as symbols of the value of learning activities;

2. Gift;

3. Competition, competition both individuals and groups can motivate students to excel;

4. Ego-involvement, by raising awareness of children to feel the importance of the task and accepting it as a challenge is one of the most important forms of motivation;

5. Giving a test, students will be keen to learn if they know there will be a test;

6. Knowing the results, knowing the learning outcomes especially if there is progress will motivate students to study hard;

7. Praise, with praise will increase the desire to learn and generate self-esteem;

8. Punishment, punishment as a negative reinforcement but if given appropriately and wisely can be a motivational tool;

9. The desire to learn, means there is an element of intent and there is an intention to learn;

10. Interest, the learning process will run smoothly if accompanied by interest;

11. A recognized goal, students will be motivated to learn if they know the purpose/importance of the material they are going to learn ${ }^{23}$.

While the efforts that can be made by teachers to increase students' learning motivation are :

a. Teachers must be able to excite students.

${ }^{22}$ Cleopatra, M. (2015). Pengaruh gaya hidup dan motivasi belajar terhadap prestasi belajar matematika. Formatif: Jurnal Ilmiah Pendidikan MIPA, 5(2).

${ }^{23}$ Suprihatin, S. (2015). Upaya guru dalam meningkatkan motivasi belajar siswa. Jurnal Pendidikan Ekonomi UM Metro, 3(1), 73-82. 
Teachers should avoid monotonous and continuous activities in the learning process, causing students to feel bored. The teacher must nurture the interests of students by giving certain freedoms in learning situations and using interesting learning methods.

b. Give realistic hope.

Teachers need to have enough knowledge about the academic success or failure of each student. So the teacher can maintain realistic student expectations and modify less or unrealistic expectations.

c. Give incentives.

Teachers are expected to give gifts to students who experience success can be in the form of praise, good numbers, and so on.

d. Directing the behavior of students

Directing students is the teacher's job. Teachers are required to be able to respond to students who are passive, not participating in learning, rowdy students by giving wise and prudent reprimands ${ }^{24}$.

Some ways that teachers can do to increase student motivation are as follows:

a. Generating interest in learning.

Generating interest in learning can be done by teachers by linking learning with students' interests and showing that the knowledge learned is very beneficial for students. This will increase curiosity and increase students' intrinsic motivation.

b. Encourage curiosity.

Skilled teachers will be able to use ways to arouse and nurture students' curiosity in learning activities. Increasing student curiosity can be done through stories, and using learning media.

c. Use a variety of interesting presentation methods

Increasing students' intrinsic motivation can be done through the use of interesting learning materials and the use of a variety of presentation methods. Varied learning methods will increase student motivation and will not make students get bored quickly.

d. Assist students in formulating learning goals.

The fundamental principle of motivation is that children will study hard to achieve goals if the goals are formulated by themselves, not

${ }^{24}$ Kurniawati, E. (2016). Guru Dan Motivasi Belajar Agama Anak Tuna Grahita. Wahana Akademika: Jurnal Studi Islam dan Sosial, 3(1), 67-76. 
formulated by others. Therefore, the teacher should encourage and help students to formulate and achieve their own learning goals ${ }^{25}$.

There are several functions of motivation, namely: 1) Encouraging people to do, motivation in this case as a driver of every activity that will be done; 2) Determine the direction of the action, ie towards the goal to be achieved; 3) Selecting actions, which determine what actions must be done to achieve the goal, by setting aside actions that are not useful for the purpose ${ }^{26}$. namely:

Tirtiana proposed four indicators of learning motivation

1. Interest in lessons;

2. Diligently facing the task;

3. Resilient in facing learning difficulties;

4. Happy to find and solve problems ${ }^{27}$.

Whereas Lestari put forward the indicators of learning motivation as follows:

1. There is encouragement and learning needs;

2. Show attention and interest in the tasks given;

3. Diligently facing the task;

4. Tenacious faces difficulties;

5. The desire and desire to succeed ${ }^{28}$.

So that learning motivation indicators can be developed as follows:

1. Interest in lessons;

2. Diligently facing the task;

3. Resilient in facing learning difficulties;

4. There is encouragement and learning needs;

25 Masni, H. (2017). Strategi Meningkatkan Motivasi Belajar Mahasiswa. Jurnal Ilmiah Dikdaya, 5(1), 34-45.

26 Emda, A. (2018). Kedudukan Motivasi Belajar Siswa Dalam Pembelajaran. Lantanida Journal, 5(2), 172-182.

${ }^{27}$ Tirtiana, C. P. (2013). Pengaruh Kreativitas belajar, Penggunaan Media Pembelajaran Power Point, dan Lingkungan Keluarga terhadap Hasil Belajar Mata Pelajaran Akuntansi pada Siswa Kelas X AKT SMK Negeri 2 Blora Tahun Ajaran 2012/2013 (Motivasi Belajar Sebagai Variabel Intervening). Economic Education Analysis Journal, 2(2), 15-23.

28 Lestari, K. E. (2014). Implementasi Brain-Based Learning untuk meningkatkan kemampuan koneksi dan kemampuan berpikir kritis serta motivasi belajar siswa SMP. Judika (Jurnal Pendidikan Unsika), 2(1). 
5. Attention to tasks;

6. Desire to succeed;

7. Happy to find and solve problems.

\section{Discussion}

\section{A. Learning Motivation and Learning Readiness as Interdependent Variables in Learning Success}

factors:

Student learning readiness is influenced by the following

1. Physical conditions that are not conducive. For example, illness, will definitely affect other factors needed for learning.

2. Poor psychological condition. For example nervous, depressed, etc. is an initial condition that is not favorable for smooth learning. Explaining readiness conditions include 3 aspects, namely: a) Physical, mental and emotional conditions, b) Needs, motives and goals, c) Skills, knowledge and other understandings that have been learned ${ }^{29}$

Factors that shape learning readiness include: 1) Equipment and physiological growth; it concerns the growth of personal equipment such as the body in general, sense media, and intellectual capacity; 2) Motivation, which involves the needs, interests and goals of individuals to maintain and develop themselves ${ }^{30}$.

Factors that affect learning readiness include: physical readiness, psychological readiness, and material readiness ${ }^{31}$. Physical readiness is closely related to health that will affect learning outcomes and individual social adjustment. Unhealthy individuals may lack vitamins, lacking the energy to study. This can affect the smooth learning process. Vice versa if the body is not sick (away from

${ }^{29}$ Widyaningtyas, A. (2012). Peran lingkungan belajar dan kesiapan belajar terhadap prestasi belajar fisika siswa kelas X Sekolah Menengah Atas Negeri 1 Pati.

${ }^{30}$ Sasmita, E. (2013). Pengaruh Kesiapan Belajar, Disiplin Belajar dan Manajemen Waktu terhadap Motivasi Belajar Mata Diklat Bekerjasama dengan Kolega dan Pelanggan pada Siswa Kelas X Program Keahlian Administrasi Perkantoran di SMK Negeri 2 Semarang (Doctoral dissertation, Universitas Negeri Semarang).

1 Yulikasari, R., \& Pramusinto, H. (2016). Pengaruh Kesiapan Belajar, Kompetensi Profesional Guru Dan Lingkungan Belajar Terhadap Motivasi Belajar Mata Pelajaran Kearsipan. Economic Education Analysis Journal, 5(3), 825-825. 
drowsiness, drowsiness, and so on). This will make it easier to learn because there is no interference from his physical condition.

Psychological readiness related to intelligence, high memory, needs that are satisfied, there is a desire or motivation to learn, can concentrate, and there is attention. Individuals in studying the material certainly must have material that can be learned or worked on, for example reading books, textbooks from school or other relevant textbooks used as reference material for learning, and have a notebook. Supported by various sources of reading it will provide knowledge and will assist students in responding to questions from the teacher related to the lesson ${ }^{32}$.

Based on the explanation above, it can be concluded that there are several factors that influence student learning readiness, namely physical, psychological, and material readiness. Physical readiness related to the condition of the student's body. Psychic readiness is related to intelligence, while material readiness includes the readiness of the tools needed in the learning process, namely: notebooks, textbooks, pencils, etc..

Learning readiness is a person's ability both physically and mentally to conduct learning activities. Learning readiness is influenced by several factors as expressed by several experts. Learning readiness is formed by two factors, namely (1) equipment and physiological growth, (2) motivation. Learning motivation is the impetus in students to carry out learning activities in order to achieve optimal achievement. The higher the motivation of student learning, the higher the students' learning readiness. Students who have high learning motivation will prepare everything needed in the learning process $^{33}$.

Research results show that learning motivation can affect learners' readiness for learning ${ }^{34}$. Conversely learning readiness can

32 Jumasrin, J. (2019). Variabel-Variabel Relasional Kesiapan Belajar Peserta Didik di Tingkat Sekolah Dasar. Shautut Tarbiyah, 25(1), 84-107.

33 Jumasrin, J. (2019). Variabel-Variabel Relasional Kesiapan Belajar Peserta Didik di Tingkat Sekolah Dasar. Shautut Tarbiyah, 25(1), 84-107.

${ }^{34}$ Yanida, A. F., \& Pramusinto, H. (2014). Pengaruh Motivasi Belajar, Disiplin Belajar dan Media Pembelajaran Terhadap Kesiapan Belajar Siswa Kelas X Administrasi Perkantoran Pada Mata Diklat Mengelola Peralatan Kantor di SMK NU 01 Kendal. Economic Education Analysis Journal, 3(3). 
affect students' learning motivation ${ }^{35}$. Thus, the two variables are mutually influencing, so it must be a concern of teachers and parents.

\section{B. Effects of Parents' Attention on Learning Readiness}

Student learning readiness is influenced by parents' attention. Parent's attention is a process of giving parents assistance to their children, encouraging to learn, giving direction to the importance of learning, paying attention to the needs of tools that support learning to achieve optimal learning achievement. At the elementary school age, children cannot prepare themselves everything needed for their learning activities. This is where the role of parents is needed to help children's learning readiness. The higher the parent's attention to their child, the higher the child's learning readiness.

Learning readiness is only an intermediate variable to lead to learning success. Learning outcomes and learning achievements become a measure of learning success. Research findings indicate that learning achievement begins with the attention of parents ${ }^{36}$. Parent's attention affects the learning outcomes of students ${ }^{37}$.

\section{Conclusions and Recommendations}

Learning success is largely determined by physical conditions, psychological, and initial knowledge about the lessons to be faced. Therefore, students must ensure their readiness comprehensively. This responsibility must start from the family environment, then by the school through the conditioning of a conducive learning environment. Psychologically, learning readiness can be influenced by motivation, both internally and externally. Students should not be left trapped in external impulses that are temporary in following learning. Instead,

${ }^{35}$ Lutviana, L., \& Suryani, N. (2015). Pengaruh Lingkungan Keluarga, Kesiapan Belajar, dan Disiplin Belajar Terhadap Motivasi Belajar Siswa Kelas XI IPS pada Mata Pelajaran Ekonomi di MA. NU Raudlatul Muallimin Wedung. Economic Education Analysis Journal, 4(1).

${ }^{36}$ Mawarsih, S. E., \& Hamidi, N. (2013). Pengaruh perhatian orang tua dan motivasi belajar terhadap prestasi belajar siswa sma negeri jumapolo. Jupe-Jurnal Pendidikan Ekonomi, 1(3).

${ }^{37}$ Nur, M. A. (2016). Pengaruh Perhatian Orang Tua, Konsep Diri, Persepsi Tentang Matematika Terhadap Hasil Belajar Matematika Melalui Motivasi Belajar Siswa Kelas VIII SMP Negeri Di Kecamatan Ujung Loe Kabupaten Bulukumba. Matematika Dan Pembelajaran, 4(2), 64-79. 
students are directed to the deepest awareness of their main mission in participating in learning. Sociologically, the role of the family through high attention can also be an important factor in achieving learning success.

As an implication of this study, there are a number of suggestions offered, namely: first, it is necessary to increase the role of schools (especially teachers) in increasing student motivation. Schools are not just institutions for learning services, but education in a broad sense. Second, parents need to increase awareness to ensure students' readiness for learning. Third, further research is needed on the role of parents in student learning readiness. It is also important to do an empirical study of the role of schools in increasing student motivation. 


\section{References}

Amaliah, D. (2016). Pengaruh Partisipasi Pendidikan Terhadap Persentase Penduduk Miskin. Faktor Jurnal Ilmiah Kependidikan, 2(3).

Angraini, S. (2018). Pengaruh Penggunaan Media Pembelajaran Lcd Projector Terhadap Perhatian Siswa Dalam Pembelajaran Ekonomi Di Sekolah Menengah Atas Negeri 1 Kampar (Doctoral dissertation, Universitas Islam Negeri Sultan Syarif Kasim Riau).

Aslamiyah, S. S., Ag, S., \& Lamongan, F. A. I. U. I. (2016). Profesionalisme Guru Dalam Perspektif Islam. Jurnal Akademika, 10(2), 180.

Chandra, A. (2018). Hubungan Perhatian Orang Tua dan Iklim Sekolah dengan Disiplin pada Siswa SMP N 2 Padang Tualang Kabupaten Langkat. Jurnal Psychomutiara, 1(1), 1-14.

Cleopatra, M. (2015). Pengaruh gaya hidup dan motivasi belajar terhadap prestasi belajar matematika. Formatif: Jurnal Ilmiah Pendidikan MIPA, 5(2).

Dacholfany, M. I. (2015). Reformasi Pendidikan Islam Dalam Menghadapi Era Globalisasi. AKADEMIKA: Jurnal Pemikiran Islam, 20(1), 173-194.

Emda, A. (2018). Kedudukan Motivasi Belajar Siswa Dalam Pembelajaran. Lantanida Journal, 5(2), 172-182.

Hamdu, G., \& Agustina, L. (2011). Pengaruh motivasi belajar siswa terhadap prestasi belajar IPA di sekolah dasar. Jurnal penelitian pendidikan, 12(1), 90-96.

Harmini, T. (2017). Pengaruh Kesiapan Belajar Terhadap Prestasi Belajar Mahasiswa Pada Pembelajaran Kalkulus. Mathline: Jurnal Matematika dan Pendidikan Matematika, 2(2), 145-158.

Idzhar, A. (2016). Peranan Guru dalam Meningkatkan Motivasi Belajar Siswa. Jurnal office, 2(2), 221-228.

Jumasrin, J. (2019). Variabel-Variabel Relasional Kesiapan Belajar Peserta Didik di Tingkat Sekolah Dasar. Shautut Tarbiyah, 25(1), 84-107.

Kurniawati, E. (2016). Guru Dan Motivasi Belajar Agama Anak Tuna Grahita. Wahana Akademika: Jurnal Studi Islam dan Sosial, 3(1), 67-76. 
Lestari, K. E. (2014). Implementasi Brain-Based Learning untuk meningkatkan kemampuan koneksi dan kemampuan berpikir kritis serta motivasi belajar siswa SMP. Judika (Jurnal Pendidikan Unsika), 2(1).

Lutviana, L., \& Suryani, N. (2015). Pengaruh Lingkungan Keluarga, Kesiapan Belajar, dan Disiplin Belajar Terhadap Motivasi Belajar Siswa Kelas XI IPS pada Mata Pelajaran Ekonomi di MA. NU Raudlatul Muallimin Wedung. Economic Education Analysis Journal, 4(1).

Manizar, E. (2015). Peran Guru Sebagai Motivator dalam Belajar. Tadrib: Jurnal Pendidikan Agama Islam, 1(2), 204-222.

Masni, H. (2017). Strategi Meningkatkan Motivasi Belajar Mahasiswa. Jurnal Ilmiah Dikdaya, 5(1), 34-45.

Mawarsih, S. E., \& Hamidi, N. (2013). Pengaruh perhatian orang tua dan motivasi belajar terhadap prestasi belajar siswa sma negeri jumapolo. Jupe-Jurnal Pendidikan Ekonomi, 1(3).

Mulyani, D. (2013). Hubungan kesiapan belajar siswa dengan prestasi belajar. Konselor, 2(1).

Nur, M. A. (2016). Pengaruh Perhatian Orang Tua, Konsep Diri, Persepsi Tentang Matematika Terhadap Hasil Belajar Matematika Melalui Motivasi Belajar Siswa Kelas VIII SMP Negeri Di Kecamatan Ujung Loe Kabupaten Bulukumba. Matematika Dan Pembelajaran, 4(2), 64-79.

Prihartanta, W. (2015). Teori-teori motivasi. Jurnal Adabiya, 1(83), 114.

Rahman, A. R. (2011). Pengaruh motivasi, lingkungan dan disiplin terhadap prestasi belajar siswa pada jurusan teknik audio video SMK Negeri 3 Yogyakarta. Jurnal. Program Studi Pendidikan Teknik Elektronika. Universitas Negeri Yogyakarta.(eprints. uny. ac. id/9495/1/Jurnal. pd. di akses September 2014).

Sasmita, E. (2013). Pengaruh Kesiapan Belajar, Disiplin Belajar dan Manajemen Waktu terhadap Motivasi Belajar Mata Diklat Bekerjasama dengan Kolega dan Pelanggan pada Siswa Kelas X Program Keahlian Administrasi Perkantoran di SMK Negeri 2 Semarang (Doctoral dissertation, Universitas Negeri Semarang).

Suprihatin, S. (2015). Upaya guru dalam meningkatkan motivasi belajar siswa. Jurnal Pendidikan Ekonomi UM Metro, 3(1), 7382. 
Thaib, E. N. (2013). Hubungan Antara prestasi belajar dengan kecerdasan emosional. JURNAL ILMIAH DIDAKTIKA: Media Ilmiah Pendidikan dan Pengajaran, 13(2).

Tirtiana, C. P. (2013). Pengaruh Kreativitas belajar, Penggunaan Media Pembelajaran Power Point, dan Lingkungan Keluarga terhadap Hasil Belajar Mata Pelajaran Akuntansi pada Siswa Kelas X AKT SMK Negeri 2 Blora Tahun Ajaran 2012/2013 (Motivasi Belajar Sebagai Variabel Intervening). Economic Education Analysis Journal, 2(2), 15-23.

Wasti, S. (2013). Hubungan Minat Belajar Dengan Hasil Belajar Mata Pelajaran Tata Busana Di Madrasah Aliyah Negeri 2 Padang. EJournal Home Economic and Tourism, 2(1).

Widyaningtyas, A. (2012). Peran lingkungan belajar dan kesiapan belajar terhadap prestasi belajar fisika siswa kelas X Sekolah Menengah Atas Negeri 1 Pati.

Yanida, A. F., \& Pramusinto, H. (2014). Pengaruh Motivasi Belajar, Disiplin Belajar dan Media Pembelajaran Terhadap Kesiapan Belajar Siswa Kelas X Administrasi Perkantoran Pada Mata Diklat Mengelola Peralatan Kantor di SMK NU 01 Kendal. Economic Education Analysis Journal, 3(3).

Yulikasari, R., \& Pramusinto, H. (2016). Pengaruh Kesiapan Belajar, Kompetensi Profesional Guru Dan Lingkungan Belajar Terhadap Motivasi Belajar Mata Pelajaran Kearsipan. Economic Education Analysis Journal, 5(3), 825-825. 